\title{
(⿹

\section{Det skal mer enn mot til for å varsle}

ANMELDELSER

NILS KRISTIAN KLEV

Spesialist i allmennmedisin, leder i Allmennlegeforeningen og leder av Legeforeningens Varslingsutvalg

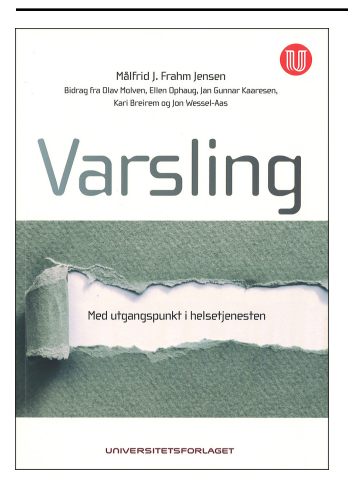

Målfrid J. Frahm Jensen

Varsling

230 s, ill. Oslo: Universitetsforlaget, 2020. Pris NOK 399

ISBN 978-82-15-03534-5

Målfrid J. Frahm Jensen har i denne boken skrevet om sine personlige erfaringer fra en varslingssak hun selv frontet i 2014, med utgangspunkt i to pasienthistorier. Hun jobbet da som erfaringskonsulent ved Stavanger universitetssykehus. I første halvdel av boken gjennomgår hun i detalj forhistorien, pasienthistoriene, hvordan hun gikk frem og hvordan hun opplevde å stå i de ulike fasene etterhvert som varslingssaken utviklet seg. I andre halvdel av boken har hun fått jurist Olav Molven, journalist Ellen Ophaug, organisasjonspsykolog og jurist Jan Gunnar Kaaresen, advokat Kari Breirem og advokat Jon Wessel-Aas til å skrive hvert sitt kapittel om temaene varslingsplikt, innsynsrett og forvaltning, arbeidsmiljø og kultur, ytringsfrihet og manglende varslervern.

Boken tar for seg de ulike sidene av en varslingssak og treffer nok med sine eksempler best studenter, personell og ledere innen helsesektoren, men er likevel generell nok også i teoridelen til at også andre kan ha nytte av den.

Varslingsinstituttet er relativt ungt i Norge og Frahm Jensens historie viser at vi fortsatt har en vei å gå før det kan fungere godt etter hensikten. Det presenteres i boken forslag til mulige forbedringer i lovverket for å bedre kunne ivareta varslerne. Det er sterkt å lese om de erfaringer Frahm Jensen gjorde seg og hvilke konsekvenser det fikk for henne å stå frem. Historien presenteres bare fra hennes side med utdrag fra kommunikasjon hun har hatt med de ulike aktørene. En kan savne et motsvar fra arbeidsgiversiden, men forståelig nok 
ville kanskje det ikke latt seg gjøre. Første del av boken blir noe lang og springende og kunne med hell vært mer strukturert og kortet noe ned. Ellers bidrar kapitlene fra de andre forfatterne til å belyse godt de ulike dimensjonene i den kompliserte saken. De refererer i noe ulik grad til den aktuelle varslingssaken, men kan også leses selvstendig av dem som ønsker en mer lærebokaktig tilnærming.

Vi er mange som kan havne i situasjoner der det er behov for å varsle. Da er det mange forhold en skal ta stilling til og sikkert mange spørsmål som vil dukke opp underveis. Denne boken belyser viktige sider i slike saker og gjør deg trolig bedre rustet samtidig som den advarer mot svakhetene i dagens system.

Publisert: 8. mars 2021. Tidsskr Nor Legeforen. DOI: 10.4045/tidsskr.20.0930 (C) Tidsskrift for Den norske legeforening 2020. Lastet ned fra tidsskriftet.no 